\title{
The Students' Self-Assessment on Their English Language Learning
}

\author{
Lely Lismay ${ }^{1}$, Putri Laila Ramadhani ${ }^{2}$ \\ ${ }^{1}$ University of Birmingham, United Kingdom,e-mail: lismayleli@gmail.com \\ ${ }^{2}$ State Islamic Institut of Bukittinggi (IAIN) Bukittinggi, e-mail:putrilaila@gmail.com
}

\begin{abstract}
(c) (1) (2)
(C)2021 by the authors. Submitted for possible open access publication under the terms and conditions of the Creative Commons Attribution-ShareAlike 4.0 International License-(CC-BY-SA) (https://creativecommons.org/licenses/by-sa/4.0/) d. DOI : https://10.30983/mj.v1i1.4891
\end{abstract}

Submission: September 21, $2021 \quad$ Revised: December 02, $2021 \quad$ Published: December 31, 2021

\begin{abstract}
Abstrak
Penelitian ditujukan untuk menggali sejaubmana siswa mampu melakukan asesmen diri dalam mempelajari Bahasa Inggris. Terdapat tiga aspek yang digali melalui asesmen diri ini, yaitu penetuan tujuan dalam mempelajari Bahasa Inggris, menentukan kompetensi yang telah dicapai, dan menentukan kompetensi yang harus dicapai. Penelitian telab dilaksanakan di Madrasah Sumatera Thawalib Parabek, provinsi Sumatera Barat, Indonesia. Penelitian ini dirancang sebagai penelitian kuantitatif. Informan dalam penelitian ini adalab 33 orang pelajar yang berasal dari kelas $V$ jurusan Agama di Madrasah Sumatera Thawalib Parabek. Angket digunakan sebagai instrument untuk mengetahui sejaubmana para siswa mampu melakukan asesmen diri. Hasil penelitian secara umum menunjukean bahwa 95\% siswa menetapkan tujuan belajar bahasa Inggris untuk hal-hal akademis, 55\% siswa belajar bahasa Inggris dengan tujuan lulus ujian masuk perguruan tinggi, dan 35\% siswa belajar bahasa Inggris untuk mencari pekerjaan. Dalam hal mengukur ketercapaian kemampuan bahasa Inggris, $85 \%$ siswa dapat menulis kalimat sederhana dengan benar, 55\% siswa dapat berbicara bahasa Inggris dengan lancar tanpa malu dan takut melakukan kesalahan, 55\% siswa dapat berbicara bahasa Inggris dengan tepat dan benar. kesalahan mereka dalam berbicara, 55\% siswa dapat memahami tugas mendengarkan, dan 75\% siswa dapat dengan mudah memahami informasi detail dalam bacaan. Dalam menentukan jenis kompetensi yang harus dicapai, 95\% siswa menempatkan berbicara lancar sebagai kompetensi pertama yang harus dicapai. Kemudian, 95\% siswa memilih kompetensi pengucapan yang harus ditingkatkan, 85\% siswa cenderung menguasai kosa kata, 75\% menjaga menulis paragraf, dan 55\% siswa memperhatikan keterampilan membaca. Disimpulkan bahwa para siswa mampu melakukan asesmen diri dalam mempelajari Bahasa Inggris. Asesmen ini tidak hanya untuk membimbing siswa untuk memiliki kesadaran dalam belajar, tetapi diharapkean berimplikasi terhadap peningkatakan kemampuan Babasa Inggris mereka.
\end{abstract}

Kata Kunci: Penilaian Diri Siswa, Pengaturan Diri Siswa, Pembelajaran Bahasa Inggris

\begin{abstract}
The research is aimed at exploring the extent to which students are able to conduct self-assessment in learning English. There are three aspects that are explored through this self-assessment, namely determining goals in learning English, determining competencies that have been achieved, and determining competencies that must be achieved. The research has been carried out at Madrasah Sumatra Thawalib Parabek, West Sumatera, Indonesia. This research was designed as a quantitative research. The informants in this study were 33 students from class V majoring in Religion at Madrasah Sumatra Thawalib Parabek. Questionnaires were used as an instrument to determine the extent to which students are able to carry out self-assessments. The results of the research generally show that $95 \%$ of students set the goal of learning English for academic matters, 55\% of students studied English with the aim of passing the college entrance exam, and 35\% of students studied English to find work. In terms of measuring the achievement of English language skills, $85 \%$ of students could write simple sentences correctly, $55 \%$ of students can speak English fluently without being ashamed and afraid of making mistakes, $55 \%$ of students could speak English correctly and correctly their mistakes in speaking, $55 \%$ of students could understand the listening task, and $75 \%$ of students could easily understand detailed information in the reading. In determining the type of competency that must be achieved, 95\% of students placed speaking fluently as the first competency that must be achieved. Then, $95 \%$ of students chose pronunciation competence that must be improved, $85 \%$ of students tend to master vocabulary, $75 \%$ kept writing paragraphs, and $55 \%$ of students paid attention to reading skills. It is concluded that the students were able to conduct self-assessment in learning English. This assessment is not only to guide students to have awareness in learning, but it is expected to have implications for improving their competency in English language.
\end{abstract}

Keywords: Students’ Self-Assessment, Students’ Self-Regulatory, English Language Learning. 


\section{Introduction}

Self-assessment is both a significant learning tool and a component of the evaluation process. This kind of assessment refers to learners' engagement in making judgments about their own learning, notably their successes and the results of their learning. It indicates that selfevaluation is required to determine how good pupils are at anything. Students can obtain their self-evaluation not only from their teachers, instructors, or educators, but also from themselves (Aliaga, M. and Gunderson, B,2002; Andrade, H., \& Boulay, B., 2003, and Andrade, H., \& Du, Y., 2005). The main purpose of self-assessment involving students carefully is to improve learning and achievement, and to promote self-managing learning (Pintrich, 2000; Zimmerman \& Schunk, 2004).Many studies have been conducted on students' self-assessment, such as student self-assessment and its influence on learning a pilot study, and students' self-assessment on their spoken interaction. Self-assessment comes from the concept of independent learning. An important aspect of self-assessment is that students reflect on their work and make their own assessments based on a set of criteria provided by the teacher Arter, J., \& McTighe, J., 2001; Black, P., Harrison, C., Lee, C., Marshall, B. \& Wiliam, D., 2003; Boud, D., \& Falchikov, N., 1989). Here, students are actively involved in the whole process, thus making learning a studentcentered process in which students are responsible for their own learning.

Self-assessment is effective in learning English, especially to motivate students to study and reflect on their own ability to master English; promote critical thinking and reflective practice in learning English; develop an attitude of self-learning in their own English learning; and fostering a commitment to learning English among many others. Self-assessment contributes to students' progress in language learning. However, to introduce and apply self-assessment in language learning for the purpose of English as a second or foreign language, there are several factors that need to be carefully considered before ESL/EFL teachers implement self-assessment for their students. ESL/EFL teachers need to take the time to explain self-assessment procedures, rubric concepts, and criteria to their students. The concept of self-assessment is very necessary to be introduced to students (Butler, D., \& Winne, P., 1995; Deci, E. L., \& Ryan, R. M., 1985; MacDonald, B., \& Boud, D., 2003). Moreover, students also need guidance in the use of rubrics and instruments. In addition, it is very important for teachers to consider the particular culture in conducting lessons where self-assessment is used.

The self-assessment is an individual review performed to identify elements that can be improve or exploited to achieve certain predefined goals. Self- assessment refers to the involvement of learners in making judgments about their own learning, particularly about their achievements and the outcomes of their learning. It is a formative tool that enables students to identify their strengths and weaknesses and that draws their attention to those aspects of their performance that need improvement (Nicol, D., \& Macfarlane-Dick, D., 2006). It does not mean that students assess themselves in the form of grades. It is just a reflection made by students on their performance, ability, or progress. Teachers who use self-assessment usually hope that their students can find "what is missing on their own, figure out what to do next, and then take responsibility for following through on next steps.

The main aim of this study is to examine the students' self-assessment of their English language acquisition. In order to determine the language learning quality, it is necessary to obtain feedback from students on their language learning. The self-regulatory depends on the objectives, planning, and expectation of success, performance, self-control, process self-assessment, and 
product self-assessment are the components that need to be examined from the students' selfassessment. That instance, the researcher wants to look at how pupils evaluate themselves when studying English.

\section{Method}

This research employed quantitative method. Quantitative research methods are concerned with the quantification and analysis of variables to obtain results. It involves the utilization and analysis of numerical data using specialized statistical techniques to answer questions such as who, how much, what, where, when, how much, and how. Clarifying this definition, Aliaga, and Gunderson (2002), describe quantitative research method as an effort to explain a problem or phenomenon through collecting data in numerical form and analyzing with the help of mathematical methods; especially statistics. The informants in this study were 33 students from class V majoring in Religion at Madrasah Sumatra Thawalib Parabek. The questionnaire was used as the instrument to find out how students apply their self-assessment to learning English

\section{Results and Discussion}

In terms of setting the goal of studying English, 95\% of students set English learning goals for academic matters, such as meeting curriculum demands, and passing exams at school. Then, $55 \%$ of students study English with the aim of passing the college entrance exam, and 35\% of students study English to seek the job. Then, in terms of measuring the achievement of English language skills, $85 \%$ of students could write correctly simple sentences, $55 \%$ of students could speak English fluently without being ashamed and afraid to make mistake, $55 \%$ of students could speak English accurately and correct their mistake in speaking. Then, 55\% of students could comprehend listening task, and $75 \%$ of students could comprehend easily detail information in the passage. In determining the type of competence that must be achieved, $95 \%$ of students placed speaking fluently as the first competences that have to achieve. Then, $95 \%$ of the students have chosen the competence of pronunciation that must be improved, $85 \%$ of students tended to master vocabulary, $75 \%$ kept the writing paragraph, and $55 \%$ of students cared for reading skill.

The findings above show that the students have been able to do self-assessment encompassing setting the goal of studying English, measuring the achievement of English language skills, and determining the type of competence that must be achieved. As indicated by the research findings, the majority of students study English more because of the academic demands of the school than long-term goal. In terms of the English language skills that have been achieved, the majority of students are more inclined to writing skills than other language skills. On the other hand, for the skills that must be achieved, the majority of students are determined to improve speaking skills, followed by the competency in pronunciation, mastering vocabulary, writing, and reading.

Self-assessing is indeed not easy, but students must be done to students must do it to guard

their goals in learning English and find out to what extent their ability to master a thing. Selfassessment can promote students' learning, raise their level of awareness of course content and assessment principles, enhance students 'knowledge, and engage students in the process of assessment, which means sharing assessment burden. As each student has a chance to evaluate his performance periodically, teachers will have the opportunity to comment constructively on 
students' performance or work and to provide them with formative feedback in a timely manner. Through self-assessment, students are directed to monitor their progress in task by comparing their performance in progress with expectations. In writing skills, for example, students are led to be able to evaluate themselves about the extent to which they are able to prepare a draft and perfect it in the form of an essay (Ross, J. A., Rolheiser, C., \& Hogaboam-Gray, A., 1999; Andrade et al., 2008).

At the empirical level, there is evidence that shows the relationship between self- assessment and self-regulation. Both self-regulation and achievement can be improved through selfassessment (Schunk, 2003). The students whose high ability for self-regulating in their learning, self-assess their work more efficiently and more often than students with low ability. In a similar way, students who have academic success can monitor and evaluate their thinking more than those who are not successful. Moreover, there is also evidence showing that interventions based on teaching self-assessment strategies (monitoring and evaluation) can improve self-regulation. In addition, the interactive self-regulation model proposed by the experts adds empirical evidence about this relationship. Therefore, as learning to evaluate one's work has positive effects on selfregulation, teaching such process should be an instructional objective. Conclusion

Self-assessment is a distinctive concept that is very important to improve the quality of education in general, and learning English in particular. Self-assessment has a strategic function to address the main problems that teachers face in teaching English, such as the lack of time for assessment due to the class arrangement and the syllabus they have to complete. The proper implementation of self-assessment can help a teacher manage his/her assessment better without any students being left behind even in a large classroom. However, self-assessment must be applied in line with the principles and indicators correctly to obtain objective results.

\section{References}

Aliaga, M. and Gunderson, B. (2002). Interactive Statistics. [Thousand Oaks]: Sage Publications.

Andrade, H., \& Boulay, B. (2003). Gender and the Role of Rubric-Referenced Self-Assessment in Learning to Write. Journal of Educational Research, 97, 21- 34.

Andrade, H., \& Du, Y. (2005). Knowing what counts and thinking about quality: students report on how they use rubrics. Practical Assessment, Research and Evaluation, 10(4). Available online at: http:// PAREonline.net/getvn.asp?vD10\&nD3.

Andrade, H., Du, Y., \& Wang, X. (2008). Putting rubrics to the test: The effect of a model, criteria generation, and rubric-referenced self-assessment on elementary school students' writing. Educational Measurement: Issues and Practices, 27(2), 3-13.

Arter, J., \& McTighe, J. (2001). Scoring Rubrics in the Classroom: Using Performance Criteria for Assessing and Improving Student Performance. Thousand Oaks, CA: Corwin Press.

Black, P., Harrison, C., Lee, C., Marshall, B. \& Wiliam, D. (2003). Assessment for Learning: Putting it into Practice. Berkshire, England: Open University Press. 
Boud, D., \& Falchikov, N. (1989). Quantitative Studies of Student Self-Assessment in Higher Education: A Critical Analysis of Findings. Higher Education, 18, 529-549.

Butler, D., \& Winne, P. (1995). Feedback and Self-Regulated learning: A theoretical synthesis. Review of Educational Research, 65, 245-28

Deci, E. L., \& Ryan, R. M. (1985). Intrinsic Motivation and self-determination in Human Behavior. New York: Plenum.

MacDonald, B., \& Boud, D. (2003). The Impact of Self-Assessment on achievement: The effects of Self-Assessment Training on Performance in External Examinations. Assessment in Education, 10, 209-220.

Nicol, D., \& Macfarlane-Dick, D. (2006). Formative Assessment and Self-Regulated Learning: A Model and Seven Principles of Good Feedback Practice. Studies in Higher Education, 31, 199-218.

Pintrich, P. (2000). "The Role of Goal Orientation in Self-Regulated Learning”. In M. Boekaerts, P. Pintrich, \& M. Zeidner (Eds.), Handbook of Self-Regulation. San Diego, CA: Academic Press.

Ross, J. A., Rolheiser, C., \& Hogaboam-Gray, A. (1999). Effects of Self-Evaluation Training on Narrative Writing. Assessing Writing, 6, 107-132.

Schunk, D. (2003). Self-Efficacy for Reading and Writing: Influence of Modeling, Goal-Setting, and Self Evaluation. Reading \& Writing Quarterly, 19, 159- 172.

Zimmerman, B., \& Schunk, D. (2004). "Self-Regulating Intellectual Processes and Outcomes: A Social Cognitive Perspective. In D. Dai \& R. Sternberg (Eds.), Motivation, Emotion, and Cognition: Integrative Perspectives on Intellectual Functioning and Development. Mahwah, NJ: Lawrence Erlbaum Associates. 